\title{
CARDIOVASCULAR RISK PREDICTORS IN CENTRAL SLOVAKIAN ROMA CHILDREN AND ADOLESCENTS: REGIONAL DIFFERENCES
}

\author{
Zuzana Hujová1, Roman Alberty ${ }^{1}$, Ivan Ahlers², Eva Ahlersová2, Edita Paulíková2, J úlia Desatníková3, \\ Drahoslav Gábor ${ }^{4}$, Františka Hrubás \\ Department of Biology, Faculty of Science, Matthias Belius University, Banská Bystrica, Slovakia \\ 2Department of Animal Physiology, Institute of Biology and Ecology, Faculty of Science, Pavol J ozef Safarik University in Košice, Slovakia \\ ${ }^{3}$ Department of Mathematics, Faculty of Science, Matthias Belius University, Banská Bystrica, Slovakia \\ ${ }^{4}$ Department of Clinical Biochemistry, F. D. Roosevelt Faculty Hospital, Banská Bystrica, Slovakia \\ ${ }^{5}$ Regional Institute of Public Health, Banská Bystrica, Slovakia
}

\begin{abstract}
SUMMARY
The objective of the study was to determine some Cardiovascular Disease (CVD) risk factors in 174 Roma children and adolescents (88 males and 86 females) aged 7-18 in 3 Central Slovakian cities (44 from Žilina, 39 from Banská Bystrica and 91 from Rimavská Sobota). Venous blood samples were drawn in the morning, after a 12 hour overnight fast for biochemical analysis. Total cholesterol (TC) and triglycerides (TG) were determined enzymatically. HDL-cholesterol (HDL-C) after selective precipitation lipoproteins containing apolipoprotein B and LDL-cholesterol (LDL-C) was calculated by the Friedewald Formula. Serum levels of apolipoproteins (apo A, apo B) were analyzed immunochemically. Concentration of lipoprotein a [Lp(a)] was analyzed by immunonephelometric method (Beckman-Coulter System). Anthropometric measurements, including weight, height, waist and hip circumference were used to calculate the sum of the body mass index (BMI) and waist to hip ratio (WHR). Measured blood pressure (BP) was used to classify for hypertension. Significant differences were determined in serum levels of $L D L-C$ ( $p<0.05$; by Tukey HSD test multiple comparison more significant difference was determined between Žilina and Rimavská Sobota $p<0.046), T G(p=0.008)$, apo A ( $p<0.001)$, $L p(a)(p=0.042)$, WHR $(p<0.001), B M I(p<0.001), S B P(p<0.001)$ and $d B P(p=0.012)$ in Roma individuals of all locality groups. The Roma population from Rimavská Sobota had (in comparison to the examined populations) statistically higher values of TC, TG, LDL-C, lower HDL-C. The population showed significant relation of TG and stress athome $(p=0.03)$ and atschool $(p=0.01), H D L-C$ and cigarette smoking $(p=0.004)$, apo A and cigarette smoking $(p=0.02)$ and socioeconomic status $(p=0.006)$, WHR and cigarette smoking $(p=0.02)$. Risk values of WHR, apo $B$ and $L p(a)$ were mostly determined in Žilina's population (WHR significantly connected with family history CVD $p=0.03$, cigarette smoking $p=0.02$ and leisure time physical activity $p<0.001$ ) and $B M I$, apo A and BP in Banská Bystrica. WHR was positively correlated to BP and negatively to HDL-C and TG only in Roma participants from Rimavská Sobota. BMI was positively correlated to systolic BP in populations from Banská Bystrica and Rimavská Sobota. The results of the study should improve the paediatric health treatment and prevention of CVD risk predictors for Roma from different cities.
\end{abstract}

Key words: Roma, regional, differences, children, adolescents, cardiovascular risk factors

Address for correspondence: Z. Hujová, Dept. of Biology Faculty of Science, Matthias Belius University, Tajovského 40, 97401 Banská Bystrica, Slovakia. E-mail: zuzana.hujova@gmail.com

\section{INTRODUCTION}

The high prevalence of cardiovascular diseases (CVD) should lead to the identification of lipid profile, anthropometry and risk factors (RF) at an early age. Their unfavourable state has been proven by many studies, observing and comparing children of different ages, gender ethnicity and locations $(1,2,3)$.

Slovak inhabitants of Roma ethnicity are considered to be a group with a higher risk of CVD prevalence (there is evidence of shorter life spans and higher mortality rate in Roma population in comparison to the general Slovak population $(4,5,6)$. In Roma children and adolescents from Eastern and Central Slovakia, important variations in lipid profile and body fat have been discovered $(7,8)$, the cause of which could be an unfavourable environment and an unhealthy lifestyle.

The Institute of Health Information and Statistics in Slovakia confirms that mortality due to CVD has increased in the last 30 years (with local variation) [for example: in the Žilina Region, the mortality rate due to ischaemic heart disease was 280.2/100 thousand inhabitants in 2002 which was 54.6\% CVD mortality and in the Banská Bystrica Region 346.57/100 thousand inhabitants, or 57.5\% CVD mortality; (9)].The study was focused on the general population, information about CVD prevalence in the Roma minority population was not ascertained.

The goal of this study is to characterize the distribution of, accumulation of and relationships between CVD risk factors in

Abbreviations used: CVD, Cardiovascular Disease; TC, Total Cholesterol; LDL-C, LDL-cholesterol; HDL-C, HDL-cholesterol; TG, Triglycerides; apolipoprotein A, apo A; apolipoprotein B, apo B; Lipoprotein a, Lp(a); BMI, Body Mass Index; WHR, Waist to Hip Ratio; BP, Blood Pressure; RF, Risk Factors 
Roma children and adolescents according to gender, age, and geographic differences and to provide more current information via analysis of the anthropometric values body mass index (BMI), waist-to-hip ratio (WHR), blood pressure (BP) and serum levels of total cholesterol (TC), LDL-cholesterol (LDL-C), HDL-cholesterol (HDL-C), triglycerides (TG), apolipoprotein A (apo A), apolipoprotein B (apo B), lipoprotein a (Lp(a)) and the influence of lifestyle factors (family history of CVD, cigarette smoking, stress at home and at school, physical fitness, socioeconomic status), which have not been previously investigated in Roma children and adolescents in Central Slovakia.

\section{MATERIAL AND METHODS}

\section{Examined Population}

The target population was represented by 174 Roma participants (including 88 males and 86 females), between the ages of 7 and 18. Some subjects are part of a larger cross-sectional biethnic study on the prevalence of CVD in childhood and thus were reported on previously (10).

Participants provided blood samples and underwent physical examinations which took place in the Žilina (44), Banská Bystrica (39) and Rimavská Sobota (91) urban areas (Central Slovakia) at their respective Pediatric Health Centers in 2003-2006.

Roma are an ethnic minority originating in northern India and living in Slovakia (with unknown exact demographic size). It has been assumed that there are up to 400000 and 500000 Roma living in Slovakia, i.e. 8.5\% of Slovakia's population, with a high counts of the child population [non-Roma Slovak inhabitants have on average 151 children/1,000 families and Roma have 420 children/1,000 families; (11)].

Multiethnic studies dealt with a selected group of the population in a population of Central Slovakia with adequate representation of the surrounding urban population (Žilina, Banská Bystrica, Rimavská Sobota). Examined subjects were divided into two age categories: 7-11 years (children) and 12-18 years (adolescents). Randomly selected individuals (50 subjects from Žilina; 50 subjects from Banská Bystrica; 100 subjects from Rimavská Sobota - with total response rate 99\% (n=198); but only healthy children and adolescents without missing data were included in this report $n=174$ ) (all subjects with illnesses, which could influence the results - hypercholesterolemia, hypertriglyceridemia, diabetes, endocrine disorders or inadequate function of the kidneys - were excluded).

The testing took place at the Pediatric Health Centers where the Roma participants provided blood samples and underwent physical examinations during 2003-2006.

\section{Anthropometry}

Measurements regularly used in paediatric practices (such as height, weight, waist and hip circumference) were obtained for each subject. BP was measured on the right arm in a seated position by mercury sphygmomanometer with $\mathrm{mmHg}$ scale (evaluated sBP >120 mmHg, dBP > $80 \mathrm{mmHg}$ ).

BMI, used for assessment of the prevalence of obesity (BMI>24.5 kg.m ${ }^{-2}$ for 7-11 yrs female, BMI>28.52 kg.m² for
Table 1. Evaluation of apolipoproteins and lipoprotein a levels

\begin{tabular}{|l|c|c|c|c|}
\hline Values & apo A (g/l) & $\begin{array}{c}\text { apo B } \\
(\mathbf{g} / \mathbf{l}) \text { male }\end{array}$ & $\begin{array}{c}\text { apo B } \\
(\mathbf{g} / \mathbf{l}) \text { female }\end{array}$ & $\mathbf{L} \mathbf{p ( a )}(\mathbf{g} / \mathbf{l})$ \\
\hline Acceptable & $1.20-1.75$ & $0.7-1.3$ & $0.6-1.2$ & $<0.30$ \\
\hline Lower/higher & $<1.20 />1.75$ & $<0.7 />1.3$ & $<0.6 />1.2$ & $0.3-0.55$ \\
\hline Pathological & - & - & - & $>0.55$ \\
\hline
\end{tabular}

12-18 yrs female and BMI $>25.13 \mathrm{~kg} \cdot \mathrm{m}^{-2}$ for $7-11$ yrs male, BMI> $28.82 \mathrm{~kg} \cdot \mathrm{m}^{-2}$ for $12-18$ yrs male as recommended by (9), was calculated as a quotient of weight and squared height in meters $\left(\mathrm{kg} . \mathrm{m}^{-2}\right)$ and WHR as derived waist to hip circumference. Waist circumference was measured in the middle between the arch of 10th rib and the top of crista iliaca (WHR $>90$ for female and WHR $>85$ for male).

Information about related lifestyle factors (family history of CVD, cigarette smoking, stress, leisure-time physical activity and socioeconomic status) was determined by a questionnaire. There were some communication problems during the collection of Romas' nutrition data (information is considered to be intimate).

\section{Blood Sampling and Lipid Analysis}

Blood was drawn between $8^{00}$ A.M. and $9^{30}$ A.M. after a 12 hour overnight fasting. Samples were analyzed in the biochemical laboratory of Roosevelt Hospital in Banská Bystrica. Blood serum levels TC, HDL-C and TG were determined enzymatically, concentration of LDL-C was calculated by the Friedewald Formula: LDL-C = TC-(HDL-C + TG/2.2).

Glucose levels were not analyzed.

Serum levels of apolipoproteins (apo A, apo B) were analyzed imunochemically. Concentration of Lp(a) was analyzed by immunonephelometric method (Beckman-Coulter System).

For comparison and evaluation of obtained results, values, which have been recommended by Czech society for atherosclerosis (12) (TC $\geq 5 \mathrm{mmol} / \mathrm{l}, \mathrm{TG} \geq 1.5 \mathrm{mmol} / \mathrm{l}, \mathrm{LDL}-\mathrm{C} \geq 3.4 \mathrm{mmol} / \mathrm{l}$, HDL-C $\leq 1 \mathrm{mmol} / \mathrm{l})$ were used.

We used an evaluation of apolipoproteins by (13) and lipoprotein a by (9) (Table 1).

\section{Statistical Evaluation}

The Kolmogorov-Smirnov and Shapiro-Wilk tests were used to determine whether the outcome variables were normally distributed. Variables are reported as mean with confidence interval. If variables were normally distributed (and after verification criteria by Levene's homogeneity of variance test), we used t-test and ANOVA (in significant associations Tukey test was used for multiple comparison). If variables were not normally distributed, we used the Mann-Whitney Test and Kruskal-Wallis Test and evaluated the variables by gender- , age- and geographicrelated groups distribution. A “p” value $<0.05$ was considered as significant. The Spearman and Pearson correlation coefficients were computed to determine the bivariate relationship between all variables. The Fisher Exact Test and Pearson dependence test was used to evaluate the relationship of CVD risk factors and lifestyle factors (were given in frequency tables). Statistical analyses were performed using the SPSS System software package. 
Table 2. The biochemical and anthropometric values according to geographic differences in examined Central Slovakian Roma children and adolescents

\begin{tabular}{|l|c|c|c|c|c|c|}
\hline \multirow{2}{*}{} & \multicolumn{2}{|c|}{ Roma from Žilina } & \multicolumn{2}{c|}{ Roma from Banská Bystrica } & \multicolumn{2}{c|}{ Roma from Rimavská Sobota } \\
\cline { 2 - 7 } & $\mathbf{p}$ & $\mathbf{9 5} \% \mathbf{C l}$ & $\mathbf{p}$ & $\mathbf{9 5} \% \mathbf{C l}$ & $\mathbf{p}$ & $\mathbf{9 5 \%} \mathbf{C I}$ \\
\hline TC & 3.86 & $(3.71-4.02)$ & 3.59 & $(3.40-3.78)$ & 3.95 & $(3.80-4.10)$ \\
\hline TG & 0.86 & $(0.72-0.99)$ & 0.79 & $(0.69-0.89)$ & 1.05 & $(0.93-1.17)$ \\
\hline LDL-C & 2.09 & $(1.97-2.21)$ & 2.16 & $(2.02-2.30)$ & 2.32 & $(2.19-2.44)$ \\
\hline HDL-C & 1.20 & $(1.12-1.28)$ & 1.13 & $(1.06-1.19)$ & 1.15 & $(1.09-1.20)$ \\
\hline apo A & 1.51 & $(1.42-1.59)$ & 1.13 & $(1.07-1.18)$ & 1.22 & $(1.17-1.26)$ \\
\hline apo B & 0.72 & $(0.67-0.77)$ & 0.71 & $(0.66-0.76)$ & 0.69 & $(0.66-0.73)$ \\
\hline Lp(a) & 407.83 & $(290.29-525.38)$ & 262.30 & $(186.28-338.33)$ & 250.44 & $(187.90-312.98)$ \\
\hline WHR & 0.88 & $(0.86-0.91)$ & 0.80 & $(0.78-0.82)$ & 0.83 & $(0.82-0.84)$ \\
\hline BMI & 17.28 & $(16.05-18.51)$ & 19.63 & $(18.81-20.46)$ & 18.25 & $(17.44-19.07)$ \\
\hline SBP & 111.61 & $(107.29-115.93)$ & 114.03 & $(110.12-117.94)$ & 103.41 & $(101.54-105.27)$ \\
\hline dBP & 72.34 & $(68.78-75.90)$ & 70.97 & $(68.35-73.60)$ & 66.65 & $(64.92-68.38)$ \\
\hline
\end{tabular}

$\mathrm{Cl}$ - confidence interval

Table 3. Kruskal-Wallis test - CVD risk predictors according to regional differences (TC a LDL-C tested by ANOVA)

\begin{tabular}{|l|c|c|c|c|c|c|c|c|c|c|c|}
\hline & TC & LDL-C & HDL-C & TG & apo A & apo B & Lp(a) & WHR & BMI & SBP & dBP \\
\hline $\begin{array}{l}\text { Asymp. } \\
\text { Sig.(p) }\end{array}$ & 0.455 & 0.022 & 0.178 & 0.008 & $<0.001$ & 0.629 & 0.042 & $<0.001$ & $<0.001$ & $<0.001$ & 0.012 \\
\hline
\end{tabular}

Statistical significance $p<0.05$

\section{RESULTS}

Subject Sample Characteristics and CVD Predictors

The values of biochemical and anthropometric parameters (Table 2) in Roma children and adolescents of all locations were classified in an acceptable range, except the Lp(a) levels of the examined subjects from Žilina and Rimavská Sobota.

Significant differences were determined in serum levels of LDL-C $(\mathrm{p}<0.05$; by Tukey HSD test multiple comparison more significant difference was determined between Žilina and Rimavská Sobota $\mathrm{p}<0.046)$, TG $(\mathrm{p}=0.008)$, apo A $(\mathrm{p}<0.001)$ and $\mathrm{Lp}(\mathrm{a})(\mathrm{p}=0.042)$ in Roma individuals of all locality groups (Table 3).

When comparing localities the highest mean values of TC, LDL-C and TG were found in Rimavská Sobota, the lowest HDL-C, apo A in Banská Bystrica and the highest apo B and $\mathrm{Lp}(\mathrm{a})$ in Žilina.

The prevalence of hypercholesterolaemia in the Roma population was completely different; in Žilina and Banská Bystrica it was absent, whereas in Rimavská Sobota prevalence of 7.7\% was found out.

The mean levels of TC and LDL-C were slightly higher in Roma males (in comparison to the Roma females, except TC of Roma females from Banská Bystrica and LDL-C from Žilina, where the means were similarly distributed).

With increasing age, TC increased in Žilina's individuals (in the group from Banská Bystrica and Rimavská Sobota levels decreased; in Roma girls from Rimavská Sobota, there was however, an increase in TC observed) and LDL-C decreased in examined subjects in all localities with increasing age. Boundary LDL-C was analyzed as the highest in subjects from Žilina, pathological levels of LDL-C were found out only in Rimavská Sobota (3.3\%).

The highest mean of TC and LDL-C was ascertained in the younger age group of boys from Rimavská Sobota. The lowest mean HDL-C was found in the group of 7-11 year-old Roma girls from Rimavská Sobota and the highest in adolescent females from Žilina.

Decreased levels of HDL-C were mostly distributed in Rimavská Sobota (35.2\%), while boundary HDL-C was found in the subjects from Banská Bystrica (33.3\%).

The mean HDL-C was similarly represented in both genders (Žilina and Rimavská Sobota) and only females from Banská Bystrica had a slightly higher mean of HDL-C.

With increasing age HDL-C decreased in the boys from Banská Bystrica and Rimavská Sobota (in Žilina it interestingly increased). In females, HDL-C increased with age (except in HDL-C females from Banská Bystrica).

The highest prevalence of hypertriglyceridaemia was observed in Rimavská Sobota (14.3\%) and the lowest one in Banská Bystrica (2.6\%).

The highest mean of serum TG occurred in adolescent females from Rimavská Sobota (the lowest mean was found in 7-11 yearold boys from Žilina). TG levels were higher in Roma females (in comparison to males, except in the Roma population from Banská Bystrica).

Among all adolescent Roma subjects an overall increase of TG was noted.

The lowest mean of apo A was noted in adolescent (males). A decrease of levels of apo A with age was found out. Decreased serum levels of apo A were mostly noted in Banská Bystrica (69.2\%). In all locality groups, significant differences in the values of apo A ( $<<0.001)$ were noted. 
Table 4. Lifestyle factors according to regional differences

\begin{tabular}{|c|c|c|c|c|}
\hline Variable & Roma & Roma from Žilina & $\begin{array}{c}\text { Roma from } \\
\text { Banská Bystrica }\end{array}$ & $\begin{array}{c}\text { Roma from } \\
\text { Rimavská Sobota }\end{array}$ \\
\hline Family history $(p<0.001)$ & $N=173$ & $N=44$ & $N=39$ & $\mathrm{~N}=91$ \\
\hline yes & $50 \%(87)$ & $9.1 \%(4)$ & $28.2 \%(11)$ & $79.1 \%(72)$ \\
\hline no & $49.4 \%(86)$ & $90.9 \%(40)$ & $69.2 \%(27)$ & $20.9 \%(19)$ \\
\hline Cigarette smoking & $N=174$ & $\mathrm{~N}=44$ & $N=39$ & $\mathrm{~N}=91$ \\
\hline smokers & $26.4 \%(46)$ & $29.5 \%(13)$ & $25.6 \%(10)$ & $25.3 \%(23)$ \\
\hline non smokers & $73.6 \%(128)$ & $70.5 \%(31)$ & $74.4 \%(29)$ & $74.7 \%(68)$ \\
\hline Stress at home & $\mathrm{N}=91$ & - & - & $\mathrm{N}=91$ \\
\hline low & - & - & - & - \\
\hline middle & $20.1 \%(35)$ & - & - & $38.5 \%(35)$ \\
\hline high & $32.2 \%(56)$ & - & - & $61.5 \%(56)$ \\
\hline Stress at school & $\mathrm{N}=91$ & - & - & $\mathrm{N}=91$ \\
\hline low & $0.6 \%(1)$ & - & - & $1.1 \%(1)$ \\
\hline middle & $24.7 \%(43)$ & - & - & $47.3 \%(43)$ \\
\hline high & $27 \%(47)$ & - & - & $51.6 \%(47)$ \\
\hline Physical activity & $N=82$ & $\mathrm{~N}=44$ & $\mathrm{~N}=38$ & - \\
\hline yes & $27 \%(47)$ & $50 \%(22)$ & $64.1 \%(25)$ & - \\
\hline no & $20.1 \%(35)$ & $50 \%(22)$ & $33.3 \%(13)$ & - \\
\hline Socio-economic status & $N=89$ & - & - & $\mathrm{N}=91$ \\
\hline low & $17.8 \%(31)$ & - & - & $34.1 \%(31)$ \\
\hline middle & $20.1 \%(35)$ & - & - & $38.5 \%(35)$ \\
\hline high & $13.2 \%(23)$ & - & - & $25.3 \%(23)$ \\
\hline
\end{tabular}

The highest mean of apo B was found out in adolescent males from Žilina and high apo B was also present in Banská Bystrica (2.6\%).

Overall, the mean of $\mathrm{Lp}(\mathrm{a})$ was above the acceptable level. The mean of Lp(a) was the highest in the population from Žilina, where high (20.9\%) and pathological levels (30.2\%) occurred. Doubly high levels were seen in adolescent boys.

The means of WHR and BMI were within the acceptable range. In comparison to the control sample, higher means of WHR and lower means of BMI were found in the Roma population.

When comparing localities the highest mean values of WHR were counted in Žilina's population (Table 3). In all locality groups, significant differences in the values of WHR and BMI $(\mathrm{p}<0.001)$ were noted (Table 3).

High WHR were mostly detected in the Roma population from Žilina (56.8\%). Concerning BMI, the highest (2.3\%) prevalence of obesity was determined in the Roma subjects from Žilina (6.8\% was the prevalence of overweight) and 7\% prevalence of overweight in subjects from Rimavská Sobota.

By gender, the mean WHR and BMI were higher in boys than girls of all locality groups. The highest WHR means were noted in the group of 7-11 year-old Roma girls from Žilina, where on contrary the lowest mean of BMI was observed.

The highest BMI mean was found out in the group of 12-18 year-old Roma adolescents from Banská Bystrica. BMI values were lower in the younger age group (in comparison to the older age group of examined subjects of all localities and each gender).
Slightly higher values of WHR occurred in the younger age group (7-11 yrs) of Roma girls; they decreased with age (to 12-18 yrs), in contrast, an increase of WHR with age was observed in boys (except for boys from Rimavská Sobota, where the values remained constant).

In the Roma population, we observed higher mean values of systolic BP in comparison to the control sample (the opposite case was found for diastolic BP, for which data is not shown).

By locality, the highest mean values of systolic BP were found out in adolescents from Banská Bystrica, diastolic BP in adolescents from Žilina. Significant differences in all localities proved to be more in $\mathrm{sBP}(\mathrm{p}<0.001)$ than $\mathrm{dBP}(\mathrm{p}=0.012)$ (Table 3$)$.

In all locality groups, the Roma boys had higher values of systolic and diastolic BP (in comparison to the Roma girls). An increase of BP values with age was noted. A high (9.1\%) prevalence of hypertension (high sBP and dBP together) was found in the Roma probands from Žilina and $10.3 \%$ in the subjects from Banská Bystrica (no prevalence of hypertension was observed in Rimavská Sobota).

\section{The Relationship Between Body Fat and the Lipid Profile}

By comparison of all localities, a correlation between elevated body fat and a change of lipid concentrations was noted only in Rimavská Sobota and was absent in other Roma groups. In Rimavská Sobota, a correlation between WHR and the increase 
of TG (-0.229) and the decrease of HDL-C (-0.222) was proved. Also, a correlation between BMI and the decrease of HDL-C $(-0.260)$ was found out.

WHR had no correlation to any other parameters in the examined subjects from Banská Bystrica and Žilina. BMI in Banská Bystrica correlated with sBP.

\section{Frequency and Cummulation of CVD Risk Predictors}

Overall, the most serious CVD risk factors in examined individuals of Roma ethnicity were evaluated as: cigarette smoking, low levels of HDL-C and high values of WHR, BP.

In Rimavská Sobota (in comparison to the other localities), the highest risk values were TC, TG, LDL-C, HDL-C; in Žilina WHR, apo B and Lp(a) and apo A and BMI in Banská Bystrica.

The highest proportion of Žilina's subjects (the subjects from Banská Bystrica had the lowest frequency) were without CVD risk predictors.

\section{Lifestyle Factors}

Environmental CVD risk factors in each examined Roma population are given in Table 4 . The Roma subjects reported a high proportion of the presence of CVD in their families (in Rimavská Sobota, approximately $3 / 4$ of population, in Banská Bystrica 1/4). Cigarette smoking is relatively highly represented (with $1 / 4$ portion of the subjects from each town, with the highest percent in Žilina).

In the examined Roma subjects from Rimavská Sobota, the factor of stress was high in occurrence (approximately half of the population). The active level of leisure time physical activity was reported only by a half of the Roma population from Žilina and Banská Bystrica (data from Rimavská Sobota is absent). Socioeconomic status was evaluated as middle or lower (only $1 / 4$ examined Roma reported high).

Relation of CVD risk predictors and life style factors, tested by dependence test (Fisher's and Pearson's), showed significant relation of WHR and CVD family history $(\mathrm{p}=0.03)$, cigarette smoking $(\mathrm{p}=0.02)$ and leisure time physical activity in Žilina $(p<0.001)$, of TG and stress at home $(p=0.03)$ and at school $(\mathrm{p}=0.01)$, HDL-C and cigarette smoking $(\mathrm{p}=0.004)$, apo A and cigarette smoking $(\mathrm{p}=0.02)$ and socioeconomic status $(\mathrm{p}=0.006)$, WHR and cigarette smoking in Rimavská Sobota (to an equal extent as Žilina $\mathrm{p}=0.02$ ).

By Pearson' test, family history of CVD is in significant realation with region, where probands live $(\mathrm{p}<0.001)$.

\section{DISCUSSION}

This study focused on CVD risk predictors according to gender, age and locality in the Roma children and adolescents from Central Slovakia.

The comparison of result by gender, higher mean values of TC, LDL-C, HDL-C (except those of the Roma from Banská Bystrica), TG, apo B, Lp(a), BMI, WHR and sBP were noted in the Roma males.

Concerning the age, higher values of TC, LDL-C and WHR were found in the younger age group. In the older age group higher TG, Lp(a), BMI and BP were observed.
HDL-C and apo A decreased in the boys with age (except in the adolescents from Žilina). The Roma population from Banská Bystrica had the highest occurrence of low apo A, HDL-C and hypertension. A high number of risk predictors were noted in the examined Roma from Žilina, where the highest mean WHR, apo $\mathrm{B}$ and Lp(a) were observed and in Rimavská Sobota the highest mean levels of serum lipids (TC, TG, LDL-C) were determined.

Statistically significant differences in serum levels of lipids, lipoproteins and apolipoproteins (LDL-C, TG, apo and Lp(a)) and the anthropometric CVD predictors (WHR, BMI, BP) in the Roma subjects correlated with locality (in relation to high distribution of environmental RFs, high family history of CVD, high frequency of cigarette smoking, high level of stress, low level of leisure time physical activity and low socioeconomic status).

When comparing localities, a correlation between increased body fat and the changes of lipid concentrations was noted only in Rimavská Sobota (where there was a relationship between WHR and the increase of TG and the decrease of HDL-C and between $\mathrm{BMI}$ and the decrease of HDL-C.

Many paediatric studies call attention to the long-term effects of urbanization on the state of health, besides the variations and differences in serum levels of lipids and body fat distribution.

Frequent hypercholesterolaemia and higher levels of TC, LDL-C and HDL-C were found in the urban Turkish children and adolescents (14). The influence of an urban environment has been shown in the higher blood cholesterol levels in urban Crete children [compared to the rural children, (1)] and urban Chinese girls [comparised to the rural aborigines, (3)] .

A complete Slovak study of 11- and 17-year-old children and adolescents showed the opposite, interestingly a higher prevalence of high-risk blood cholesterol (21\%) of the rural population in comparison to the urban one (19.05\%). Significant differences in TC between the population of children living in cities and in the country $(\mathrm{p}<0.001)$ are the result of differing lifestyles (9).

The values of anthropometric indicators are generally higher in children from urban environment than from rural areas (15). Similar trends in the increased number of obese were longitudinally observed in Swedish and Spanish adolescents living in cities and in the country.

A threefold and tenfold higher occurrence of overweight and obesity was demonstrated comparing the urban and rural children from Brazil and China respectively (1).

In the Mid-Taiwan Study (Taichung City, 10-11-year-old), the presence of overweight was more frequent among urban Chinese boys compared to aborigines, but higher values of BMI (20.7 versus $17.83 \mathrm{~kg} / \mathrm{m}^{2}$ ) and percentage of overweight (46.3 versus $21.28 \%$ ) were found in the rural aboriginal females [in comparison to the urban Chinese females, (3)], which shows the ethnic and gender variability.

The Roma children and youth from Central Slovakian cities seemed to be at higher-risk than the population of nonRoma [in comparison to the control sample, lower mean serum levels of TC, LDL-C, HDL-C and TG and higher mean levels of apo A and Lp(a) were analyzed (10)] and than Roma children from Eastern Slovakia represented by mostly rural areas (7).

In the Slovak study of children and adolescents, the higher mean levels of TC were noted in the Roma minority in Banská Bystrica in comparison to Žilina’s Roma population (9) although we had the opposite results in our analyses. 
The most high-risk levels of Lp(a) determined in the population from Žilina correlated with apo B and WHR, contrary to other locality groups.

The approximately $10 \%$ prevalence of hypertension, noted in the Central Slovakian cities Žilina and Banská Bystrica is relatively high. This may be the result of urban environmental factors specific to the localities. CVD incidence is directly related to unhealthy life style, which is specific to the Roma population.

Instead of supposed absence of knowledge about CVD, Roma probands reported rather high (50\%) family history of CVD. Present family history of premature coronary diseases correlated with locality (with interesting relation to higher values of WHR in Žilina's probands).

High prevalence of cigarette smoking in the Roma children and adolescents, with negative influence of passive smoking is an important modifier of CVD development during child's age (shows its relation with WHR in Žilina and antiatherogenic HDLC, apo A in Rimavská Sobota ).

Socioeconomic situation (connected with unhealthy dietary habits) significantly affects the health of children in general (1) and is very poor in the Central Slovakian Roma population in particular. The higher caloric intake in the immigrant population always leads to worse changes in lipid profile and to the development of obesity compared to the population more adapted to Westernized nutrition.

Growing claims of location of the Roma and related physical inactivity [bad physical condition has been already shown in young Roma population, (16)] are reflected in the risk markers of CVD (high WHR in Žilina).

The rather higher prevalence of the CVD risk predictors in the Roma examined participants is consistent with analyses of the Roma adults $(4,16)$. In the complete Slovak study of the majority and minority population of children and adolescents, which assessed the frequency of three risk predictors (distribution of risk TC, BP and obesity together) a higher proportion was noted in Banská Bystrica (0.18\%) than in Žilina (0.07\%) (15), which was found to be the opposite in our study. By locality, we evaluated a heterogeneity of CVD risk markers in each of the examined population. Longitudinal examinations could compare the unknown trend of development of changes in the risk parameters of serum lipids, lipoproteins and apolipoproteins and anthropometric values in the Roma children and adolescents.

The higher proportion of the CVD risk predictors in the Roma population of children and adolescents should lead to specific application of preventive programs and the increase of paediatric medical treatment in selected cities in Central Slovakia.

\section{Acknowledgments}

The authors thank the director of the Department of Clinical Biochemistry, F. D. Roosevelt Faculty Hospital in Banská Bystrica for the possibility of biochemical analyses

Research was performed with the financial support of the grants UMB no. 984/2002, UMB no. 1251 and VEGA 1/2345/05 for epidemiological examinations of the Roma population from Central Slovakia.

\section{REFERENCES}

1. Manios Y, Magkos F, Christakis G, Kafatos AG. Twenty-year dynamics in adiposity and blood lipids of Greek children: regional differences in Crete persist. Acta Paediatr. 2005 Jul;94(7):859-65.

2. Brotons C, Ribera A, Perich RM, Abrodos D, Magaña P, Pablo S, et al. Worldwide distribution of blood lipids and lipoproteins in childhood and adolescence: a review study. Atherosclerosis. 1998 Jul;139(1):1-9.

3. Han HK, Lin T, Wu SF, Chen W, Tsai CH, Kao A, et al. A comparative study on body figure and serum lipid profile between aboriginal and Chinese elementary achoolchildren in mid-Taiwan. Endocr Res. 2003 Nov;29(4):383-8.

4. Zacharová M. Global risks of atherosclerosis in Gypsy population in Slovakia. Bratislava: 2003. (In Slovak.)

5. Vozarova de Courten B, de Courten M, Hanson RL, Zahorakova A, Egyenes HP, Tataranni PA, et al. Higher prevalence of type 2 diabetes, metabolic syndrome and cardiovascular diseases in gypsies than in nongypsies in Slovakia. Diabetes Res Clin Pract. 2003 Nov;62(2):95-103.

6. Ginter E. What is the life span of Slovakian gypsies? Med Monitor. 2002 May;5:16-7. (In Slovak.)

7. Sanitriková Z, Petrášová D, Bernasovská J, Poráčová J, Koval J, Kuchta M. Monitoring of selected prevention markers of atherosclerosis in Gypsy children. Lab Diag. 2004 Jan;1:60. (In Slovak.)

8. Alberty R, Cudráková Z, Albertyová D, Gábor D, Palková A. Distribution and correlates of lipoprotein (a) in Romanes children from Central Slovakia. A. Prelimenary report. Prague: Pathological Society of Clinical Physiology ČLS J.E. Purkyně; 2004.

9. Šimurka P, Ďatel'ová M, Rosipal Š. Primary prevention of atherosclerosis in child's age. Slovakian project MZ SR. Martin: Osveta; 2003. (In Slovak.)

10. Hujová Z, Desatniková J, Gabor D. Some cardiovascular risk factors in Gypsy children and adolescents from Central Slovakia. Bratisl Lek Listy. 2009 Apr;110(4):233-9.

11. Koupilová I, Epstein H, Holčík J, Hajioff S, McKee M. Health needs of the Roma population in the Czech and Slovak Republics. Soc Sci Med. 2001 Nov;53(9):1191-204.

12. Šamánek M, Urbanová Z. Prevention of atherosclerosis in childs' age. 1th ed. Prague: Galén; 2003. (In Czech.)

13. Labmed [Internet]. Košice: Labmed; 2006 [cited 2010 Mar 12]. Available from: www.labmed.sk/laboratome-diagnostika/biochemia/zoznam.deti.

14. Uçar B, Kiliç Z, Dinleyici EC, Colak O, Güneş E. Serum lipid profiles including non-high density lipoprotein cholesterol levels in Turkish school-children. Anadolu Kardiyol Derg. 2007 Dec;7(4):415-20.

15. Booth ML, Macaskill P, Lazarus R Baur LA. Sociodemographic distribution of measures of body fatness among children and adolescents in New South Wales, Australia. Int J Obes Metab Disord. 1999 May;23(5):456-62.

16. Krajčovičová-Kudláčková $M$, Blažíček P, Spustová V, Valachovičová M, Ginter, E. Cardiovascular risk factors in young Gypsy population. Bratisl Lek Listy. 2004 Jul-Aug;105(7-8):256-9. 